\title{
Sensitive derivative spectrophotometric determination of gold(III) using 3,5-dimethoxy-4-hydroxybenzaldehyde isonicotinoyl hydrazone (DMHBIH) in presence of micellar medium
}

\author{
G.V.S. VALLINATH ${ }^{1 *}$, K.B. CHANDRASEKHAR ${ }^{1}$, N. DEVANNA ${ }^{1}$ \\ ${ }^{1}$ Department of Chemistry, JNTU, Anantapur, Anantapur-515002, Andhra Pradesh, India \\ * Corresponding author. Tel.: +91-98495-15835; e-mail: vallinath999@gmail.com
}

Received January 27, 2010; accepted May 18, 2011; available on-line November 8, 2011

A simple and sensitive spectrophotometric method has been developed for the determination of gold(III) using the newly synthesized reagent 3,5-dimethoxy-4-hydroxybenzaldehyde isonicotinoyl hydrazone (DMHBIH) in a neutral surfactant of Triton X-100 (5\%) (micellar medium). Gold(III) forms an orange

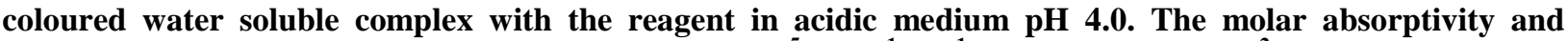
Sandell's sensitivity of the coloured species are $1.14 \times 10^{5} \mathrm{l} \mathrm{mol}^{-1} \mathrm{~cm}^{-1}$ and $0.004587 \mu \mathrm{g} / \mathrm{cm}^{2}$, respectively. Beer's law is obeyed in the range $0.197-1.97 \mu \mathrm{g} / \mathrm{ml}$ of $\mathrm{Au}(\mathrm{III})$ at $\lambda_{\max }$ at $386 \mathrm{~nm}$. The developed derivative spectrophotometric method was satisfactorily applied for the determination of gold(III) in synthetic mixtures, certified reference materials, water samples and pharmaceutical samples.

Gold(III) / 3,5-dimethoxy-4-hydroxybenzaldehyde isonicotinoylhydrazone (DMHBIH) / Micellar medium / Derivative spectrophotometry

\section{Introduction}

Gold, in its pure state is considered the most beautiful and hence most valuable of the pure metals. It is metallic, having a yellow colour when in mass, though when finely divided it may be black, ruby or purple. Gold is soft, ductile and the most malleable of metals, and because of this is usually alloyed to give improved strength and durability. Gold is a good conductor of heat and electricity, and is unaffected by air, nitric, hydrochloric, or sulphuric acid and most other reagents.

The most common gold compounds are auric chloride $\left(\mathrm{AuCl}_{3}\right)$ and chlorauric acid $\left(\mathrm{HAuCl}_{4}\right)$. Gold has eighteen isotopes. It is chiefly used for coinage, ornaments, jewellery etc.

Green gold (an alloy of gold, silver and copper 14 to 18 karats) is generally used for jewellery. Coinage gold contains gold and copper in slightly varied amounts. Australian gold contains silver instead of copper.

Gold is used in textile industry, gold flake is used for a radiation control coating for space craft, in electronic tubes, as gold-plated grid wire. Gold powder and gold sheet are used for soldering semiconductors and as a plating material. Gold alloys have a number of applications, e.g. gold-gallium and gold-antimony alloys are used in electronic industry, gold-silver or gold-platinum alloys have dental applications, are used as a rejuvenator and for anti cancer treatments.

The potential analytical applications of hydrazone derivatives have been reviewed by Singh et al. [1]. Hydrazones are an important class of known analytical reagents [2-11]. They react with many metal ions forming colour complexes and act as chelating agents. In general the technique of solvent extraction is widely used in the spectrophotometric determination of metal ions. However, organic solvents such as benzene and chloroform are often carcinogenic, toxic and cause environmental pollution. It is significant to develop a method which does not involve solvent extraction. A micellar solution has the ability to enhance the stability of metal complexes and has been utilized as a medium for the spectrophotometric determination of metal chelates [12-15].

The present paper describes a new, very simple, rapid, sensitive and derivative spectrophotometric determination of gold(III) in micellar medium. The method consists of the formation of an orange coloured metal complex using 3,5-dimethoxy4-hydroxybenzaldehyde isonicotinoyl hydrazone (DMHBIH) with gold(III) and the stability of the complex in presence of a micellar solution of Triton $\mathrm{X}-100(5 \%)$ is presented. 


\section{Experimental}

A Shimadzu 160A microcomputer based UV-VIS spectrophotometer equipped with $1.0 \mathrm{~cm}$ quartz cells was used for all spectral measurements. The instrumental parameters were optimized and the best results were obtained with scan speed $2400 \mathrm{~nm} / \mathrm{min}$, slit width $1 \mathrm{~nm}$ and $\Delta \lambda=2 \mathrm{~nm}$ for first order derivative mode in the wavelength range 350-650 $\mathrm{nm}$. An ELICO L1-120 digital pH-meter was used for the pH adjustments.

All chemicals used were of A.R. grade unless stated. All solutions were prepared with doubly distilled water. The standard gold(III) solution $(0.01 \mathrm{M})$ was prepared by dissolving accurately weighed $0.34 \mathrm{~g}$ of hydro auric chloride $\left(\mathrm{HAuCl}_{4}\right)$ in a few $\mathrm{ml}$ of doubly distilled water and made up to the mark in a 100-ml of volumetric flask. The stock solution was standardised by standard procedure. The working solutions were prepared by diluting the stock solution to an appropriate volume. Aqueous solution of $5 \%$ Triton X-100 was prepared by diluting $5 \mathrm{ml}$ of Triton X-100 (A.R. Merck) to $100 \mathrm{ml}$ with doubly distilled water. Buffer solutions were prepared by using $0.1 \mathrm{M} \mathrm{HCl}, 0.1 \mathrm{M} \mathrm{NaOH}, 0.1 \mathrm{M}$ disodium hydrogen phosphate and $0.1 \mathrm{M}$ potassium dihydrogen phosphate. Solutions of various ions of suitable concentrations were prepared using A.R. grade chemicals.

The reagent 3,5-dimethoxy-4-hydroxybenzaldehydeisonicotinoylhydrazone (DMHBIH) was synthesized by refluxing equimolar amounts of 3,5dimethoxy-4-hydroxybenzaldehyde and isonicotinoyl hydrazone. In a $250 \mathrm{ml}$ round bottomed flask a hot ethanolic solution of 3,5-dimethoxy-4-hydroxybenzaldehyde (1.8212 g, 0.01 mole) and a hot ethanolic solution of isonicotinoylhydrazone $(1.3714 \mathrm{~g}, 0.01$ mole $)$ were mixed and refluxed using a water condenser for 3 hours. On cooling the reaction mixture, a greenish yellow coloured product separated out, which was collected by filtration and washed with double distilled water.

The resulting hydrazone was recrystalized using $50 \%$ ethanol (yield $76 \%$, m.p. $221^{\circ} \mathrm{C}$ ). The structure of DMHBIH was confirmed based on the IR, NMR and mass spectral data (see Table 1) and is given in Fig. 1.

The reagent solution $(0.01 \mathrm{M})$ was prepared by dissolving $0.3022 \mathrm{~g}$ of DMHBIH in $100 \mathrm{ml}$ of dimethylformamide (DMF). The reagent solution is stable for 48 hours.

The reactions of some important metal ions were tested at different $\mathrm{pH}$ values. The samples were prepared in $10 \mathrm{ml}$ volumetric flasks by adding buffer solution $3.0 \mathrm{ml} \mathrm{(pH} \mathrm{1-11),} \mathrm{metal} \mathrm{ion} 0.5 \mathrm{ml}$ of $1 \times 10^{-3} \mathrm{M}$, Triton X-100 (5\%) $0.5 \mathrm{ml}$ and DMHBIH $0.5 \mathrm{ml}$ of $1 \times 10^{-2} \mathrm{M}$ solution. The mixture was diluted up to the mark with distilled water. The absorbance was measured in the $300-700 \mathrm{~nm}$ range against reagent blank. The results are summarized in Table 2 .

Table 1 Spectral data of of the DMHBIH reagent: a) IR spectral bands $\left(\mathrm{cm}^{-1}\right)$, b) ${ }^{1} \mathrm{H}$ NMR $(200 \mathrm{MHz})$ spectrum recorded in DMSO-d6 solvent. The mass spectrum showed that a molecular ion peak at $\mathrm{m} / \mathrm{z} 302.2$ a)

$(\mathrm{M}+1)$ corresponding to molecular weight.

\begin{tabular}{c|c}
\hline Bands $\left(\mathrm{cm}^{-1}\right)$ & Assignments \\
\hline $3429.03(\mathrm{~s}, \mathrm{br})$ & $\mathrm{v}$ NH stretching \\
$2924.16(\mathrm{~m})$ & $\mathrm{v}$ OH stretching \\
$1658.62(\mathrm{~s})$ & $\mathrm{v}$ C=O stretching \\
$1578.92(\mathrm{~s})$ & $\mathrm{v}$ C=N stretching \\
$1514.12(\mathrm{~m})$ & $\mathrm{v}$ C=N stretching (pyridine ring) \\
$1372.71(\mathrm{w})$ & $\mathrm{v}$ N-H stretching (primary amide) \\
$1123.66(\mathrm{~m})$ & $\mathrm{v}$ C-H bending \\
$836.12(\mathrm{~m})$ & $\mathrm{v}$ C-C bending \\
$749.239(\mathrm{~m})$ & \\
$689.53(\mathrm{~s})$ & \\
\hline
\end{tabular}

b)

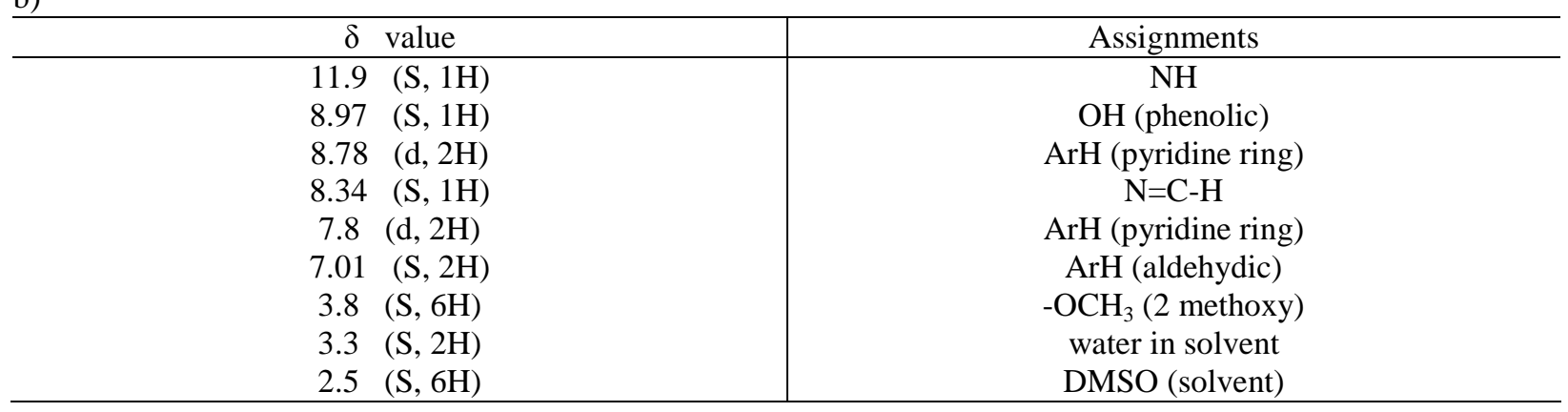


Table 2 Analytical characteristics of 3,5-dimethoxy-4-hydroxybenzaldehyde isonicotinoylhydrazone.

\begin{tabular}{l|l|l|l}
\hline Metal ion & $\mathrm{pH}$ & $\lambda_{\max }(\mathrm{nm})$ & Molar absorptivity $\varepsilon\left(1 \mathrm{~mol}^{-1} \mathrm{~cm}^{-1}\right)$ \\
\hline $\mathrm{Ru}(\mathrm{III})$ & 4.25 & 390 & $1.7 \times 10^{4}$ \\
$\mathrm{Fe}(\mathrm{III})$ & 4.0 & 386 & $1.875 \times 10^{4}$ \\
$\mathrm{Au}(\mathrm{III})$ & 4.0 & 386 & $1.14 \times 10^{5 \mathrm{a}}$ \\
\hline
\end{tabular}

${ }^{\mathrm{a}}$ present work<smiles>COc1cc(/C=N/NC(=O)c2ccncc2)cc(OC)c1O</smiles>

Fig. 1 Structure of 3,5-Dimethoxy-4-hydroxybenzaldehyde isonicotinoylhydrazone (DMHBIH).

For the spectrophotometric determination of gold(III), an aliquot of the solution containing 0.197 to $1.97 \mu \mathrm{g} / \mathrm{ml}$ of $\operatorname{gold}(\mathrm{III}), 3.0 \mathrm{ml}$ of buffer solution (pH 4.0), $0.5 \mathrm{ml}$ of $5 \%$ Triton $\mathrm{X}-100$ and $0.5 \mathrm{ml}$ of $5 \times 10^{-3} \mathrm{M}$ DMHBIH reagent solution were taken in a $10 \mathrm{ml}$ volumetric flask and the solution was diluted up to the mark with doubly distilled water. The absorbance was read at $386 \mathrm{~nm}$ in a $1.0 \mathrm{~cm}$ cell against a reagent blank prepared in the same way. The measured absorbance was used to compute the amount of gold(III) from the predetermined calibration curve.

The first-order derivative spectrum was recorded with scan speed "fast" having a degree of freedom 9 , in the wave length range $350-650 \mathrm{~nm}$. The derivative peak height was measured by the peak-zero method at $450 \mathrm{~nm}$. The peak height was plotted against the amount of gold(III) to obtain the calibration curve. The second order derivative spectrum of the $\mathrm{Au}(\mathrm{III})-$ DMHBIH system was recorded with reference to the reagent blank in the wave length range $350-650 \mathrm{~nm}$. In the second order derivative spectrum the peak height at $470 \mathrm{~nm}$ was measured from the zero line of spectrum. The calibration plot was constructed by plotting the derivative amplitude against the amount of gold(III).

\section{Results and discussion}

The reagent 3,5-dimethoxy-4-hydroxybenzaldehydeisonicotinoylhydrazone (DMHBIH) was easily synthesized as any other Schiff base reagent. The new chromogenic reagent DMHBIH was not used for the spectrophotometric determination of gold(III).
The colour reactions of some important metal ions with DMHBIH are summarized in Table 2. The colour reactions are mainly due to complex formation of DMHBIH with divalent, trivalent, tetravalent metal ions such as $\mathrm{Cu}(\mathrm{II}), \mathrm{Fe}(\mathrm{III}), \mathrm{Pt}(\mathrm{IV})$, and $\mathrm{Au}(\mathrm{III})$ in acid medium / alkaline medium to give intense coloured complexes. In acidic medium, the ligand presumably co-ordinates the metal ion as di-anion to give neutral complexes.

The absorption spectra of DMHBIH and its gold(III) complex under the optimum conditions are shown in Figs. 2,3. The Au(III)-DMHBIH complex shows the maximum absorbance at $386 \mathrm{~nm}$, where the reagent blank does not absorb appreciably.

Gold(III) reacts with DMHBIH in acidic buffer to give orange coloured water soluble species. The colour reaction between gold(III) and DMHBIH was instantaneous even at room temperature in $\mathrm{pH}$ range 3.0-5.0, the maximum colour intensity was observed at $\mathrm{pH} 4.0$ in presence of neutral surfactant Triton $\mathrm{X}-100(5 \%)$.

A slow decrease in absorbance was observed for the coloured species after $15 \mathrm{~min}$. The stability of the complex was increased by adding neutral surfactant Triton X-100. The absorbance of Au(III)-DMHBIH remains constant for more than 6 hours.

The effect of surfactants such as Triton X-100, sodium dodecyl benzene sulphonate (SDBS) and cetyl trimethyl ammonium bromide(CTAB) on the absorption profiles of the system has been investigated and presented in Table 3. In presence of Triton X-100 $(5 \%)$ the complex is more stable and exhibited maximum absorbance. Hence Triton X-100 (5\%) has been selected for further studies. 
Table 3 Influence of different surfactants on the Au(III)-DMHBIH complex.

\begin{tabular}{l|l|l}
\hline Surfactant & Type & Absorbance at 386 nm \\
\hline None & & 0.793 \\
Triton X-100 $(5 \%)$ & Neutral & 1.65 \\
CTAB $(5 \%)$ & Cationic & 0.717 \\
SDBS $(5 \%)$ & Anionic & 0.888 \\
\hline
\end{tabular}

Table 4 Physico-chemical and analytical characteristics of $\mathrm{Au}(\mathrm{III})-\mathrm{DMHBIH}$.

\begin{tabular}{l|l}
\hline Characteristics & Results \\
\hline Colour & orange \\
$\lambda_{\max }(\mathrm{nm})$ & 386 \\
$\mathrm{pH}$ range (optimum) & $3.0-5.0$ \\
Mole of reagent required per mole of metal ion for full colour development & 10 folds \\
Molar absorptivity $\left(1 \mathrm{~mol}^{-1} \mathrm{~cm}^{-1}\right)(\varepsilon)$ & $1.14 \times 10^{5}$ \\
Sandell's sensitivity $\left(\mu \mathrm{g} / \mathrm{cm}^{2}\right)$ & 0.004587 \\
Beer's law validity range $(\mu \mathrm{g} / \mathrm{ml})$ & $0.197-1.97$ \\
Optimum concentration range $(\mu \mathrm{g} / \mathrm{ml})$ & $0.482-2.642$ \\
Composition of complex $(M: L)$ obtained by the Job and mole ratio methods & $1: 1$ \\
Stability constant of the complex & $29.40 \times 10^{7}$ \\
Standard deviation & 0.00011 \\
Relative standard deviation $(\%)$ & 0.03 \\
\hline
\end{tabular}

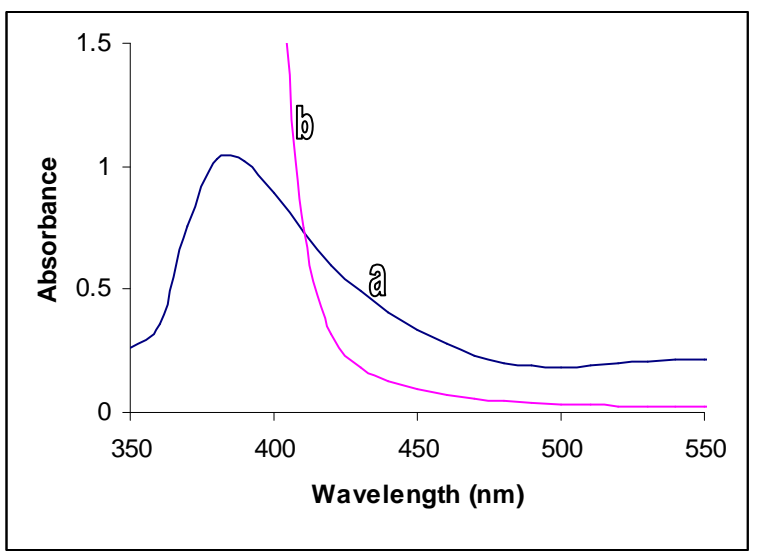

Fig. 2 Zero order absorption spectra: (a) (III)DMHBIH complex of $0.197 \mu \mathrm{g} / \mathrm{ml} \mathrm{Au(III);} \mathrm{(b)}$ reagent (DMHBIH) vs. DMF blank.

When varying the amounts of $5 \%$ Triton X-100 solution from $0.5 \mathrm{ml}$ to $4.0 \mathrm{ml}$, constant absorbance was obtained from $0.5 \mathrm{ml}$. The absorbance remains constant up to $4.0 \mathrm{ml}$ of $5 \%$ Triton $\mathrm{X}-100$. Hence $0.5 \mathrm{ml}$ of $5 \%$ Triton $\mathrm{X}-100$ was sufficient in all analytical studies. Triton X-100 serves to stabilize and sensitize the metal complex. Similarly, when varying the volume of reagent DMHBIH $\left(5 \times 10^{-3} \mathrm{M}\right)$ from $0.5 \mathrm{ml}$ to $4.0 \mathrm{ml}$, constant absorbance was obtained from $0.5 \mathrm{ml}$, therefore a 10-fold molar excess of reagent is adequate for full colour development.

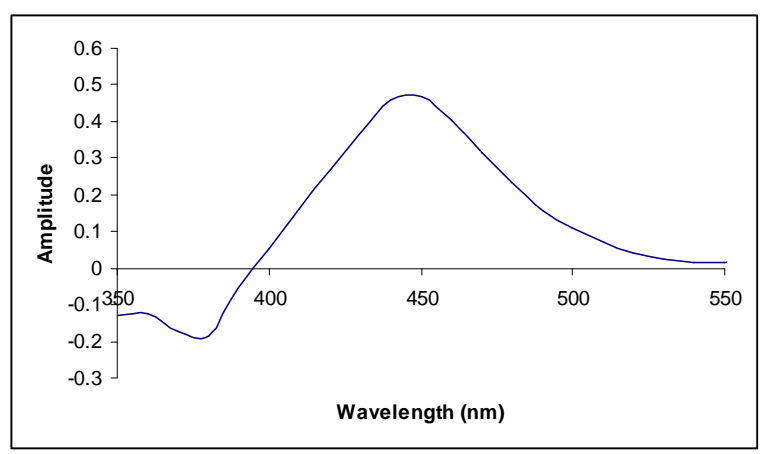

Fig. 3 First order derivative spectra of $\mathrm{Au}(\mathrm{III})$ DMHBIH complex.

The order of addition of buffer solution, metal ion, Triton X-100 and reagent has no adverse effect on the absorbance of the Au(III)-DMHBIH complex. Beer's law is obeyed in the range 0.197 to $1.97 \mu \mathrm{g} / \mathrm{ml}$. The molar absorptivity and Sandell's sensitivity of the $\mathrm{Au}(\mathrm{III})$-DMHBIH complex was obtained from Beer's law. The linear regression analysis of the absorbance at $\lambda_{\max }$ of the complex against metal ion $(\mu \mathrm{g} / \mathrm{ml})$ shows a good linear fit (Fig. 4). The various important analytical characteristics of the gold(III) DMHBIH complex are summarized in Table 4.

The first order derivative spectral graph is shown in Fig. 5. It shows that the derivative amplitudes measured at $450 \mathrm{~nm}$ for first order were found to be proportional to the amount of gold(III). 
Table 5 Tolerance limit of foreign ions on the determination of $2.4625 \mu \mathrm{g} / \mathrm{ml}$ gold(III).

\begin{tabular}{|c|c|c|c|}
\hline Ion added & Tolerance limit $(\mu \mathrm{g} / \mathrm{ml})$ & Ion added & Tolerance limit $(\mu \mathrm{g} / \mathrm{ml})$ \\
\hline Bromide & 3196.16 & $\mathrm{~Pb}^{2+}$ & 104 \\
\hline Iodide & 2538 & $\mathrm{Hg}^{2+}$ & 99 \\
\hline Urea & 1500 & $\mathrm{Ca}^{2+}$ & 80 \\
\hline Chloride & 1064 & $\mathrm{Zn}^{2+}$ & 65 \\
\hline Tetraborate & 970 & $\mathrm{Sb}^{3+}$ & 61 \\
\hline Sulphate & 940 & $\mathrm{Cd}^{2+}$ & 56 \\
\hline Oxalate & 880 & $\mathrm{U}^{6+}$ & 12.0 \\
\hline Nitrate & 620 & $\mathrm{Ag}^{+}$ & 11.0 \\
\hline Acetate & 590 & $\mathrm{Co}^{2+}$ & 6.0 \\
\hline Thiocyanide & 581 & $\mathrm{Sn}^{2+}$ & 6.0 \\
\hline Phosphate & 475 & $\mathrm{Mo}^{6+}$ & 5.0 \\
\hline Ascorbic acid & 176 & $\mathrm{As}^{3+}$ & 4.0 \\
\hline Tartarate & 148 & $\mathrm{Ni}^{2+}$ & 3.0 \\
\hline Thiourea & 115 & $\mathrm{Cr}^{3+}$ & 2.59 \\
\hline Fluoride & 95 & $\mathrm{~V}^{5+}$ & 2.54 \\
\hline $\mathrm{W}^{6+}$ & 184 & $\mathrm{Al}^{3+}$ & 1.4 \\
\hline $\mathrm{Sr}^{2+}$ & 175 & $\mathrm{Zr}^{4+}$ & 1.0 \\
\hline $\mathrm{Ba}^{2+}$ & 137 & $\mathrm{Pd}^{2+}$ & 1.0 \\
\hline $\mathrm{Mn}^{2+}$ & 110 & $\mathrm{Ru}^{3+}$ & 1.0 \\
\hline $\mathrm{Bi}^{3+}$ & 105 & $\mathrm{Cu}^{2+} *$ & $0.63,1.27^{\mathrm{a}}$ \\
\hline
\end{tabular}

${ }^{\mathrm{a}}$ masked by thiourea $245 \mu \mathrm{g} / \mathrm{ml}$

Table 6 Determination of gold(III) in synthetic mixtures.

\begin{tabular}{c|c|c|c|c}
\hline \multirow{2}{*}{ Sample No. } & \multirow{2}{*}{ Composition of the mixture $(\mu \mathrm{g} / \mathrm{ml})$} & \multicolumn{2}{|c|}{ Gold(III) $(\mu \mathrm{g} / \mathrm{ml})$} & \multirow{2}{*}{ Recovery $(\%)$} \\
\cline { 3 - 4 } & Au(III) & Added & Found $^{\mathrm{a}}$ & \\
\hline 1 & As in $1+\mathrm{Na}(25)+\mathrm{Be}(\mathrm{II})(25)$ & 0.5 & 0.48 & 96 \\
2 & As in 2 + Zn (25)+ Co (25) & 0.5 & 0.49 & 98 \\
3 & As in 3 + Ca (25) + Cr(III) (25) & 0.5 & 0.5 & 100 \\
4 & As in 4 + Mn(II) (25)+ Ag(I) (10) & 0.5 & 0.51 & 102 \\
5 & As in 5 + Ni(II) (25) + Hg(II) (25) & 0.5 & 0.53 & 106 \\
6 &
\end{tabular}

${ }^{a}$ average of best three determinations among five determinations

The stoichiometry of the complex was found to be 1:1 (metal:ligand) investigated by Job's continuous variation method and the molar ratio method, with a stability constant $29.4 \times 10^{7}$.

The effect of various diverse ions on the determination of $2.4625 \mu \mathrm{g} / \mathrm{ml} \mathrm{Au}$ (III) and tolerance limit of foreign ions was studied. The tolerance limit of a foreign ion was taken as the amount of foreign ion required to cause an error of $\pm 2 \%$ in the absorbance or amplitude. The results are given in Table 5. The data obtained in the derivative method is also incorporated. The data suggest that several associated anions and cations, such as iodide, nitrate, thiosulphate, thiocyanide, bromide, sodium(I), calcium(II), bismuth(III), tungsten(VI), do not interfere when they are present in large excess. The tolerance limit values for many anions and cations are higher in the derivative method. The interference of associated metal ion such as copper(II) is decreased by adding the masking agent thiourea.

\section{Applications}

The proposed method was applied for the determination of gold(III) in synthetic mixtures, certified reference materials, water samples and pharmaceutical samples.

\subsection{Determination of gold(III) in synthetic mixtures}

Several synthetic mixtures of varying compositions containing gold(III) and diverse ions of known concentrations were determined by the present method; and the results were found to be highly reproducible. The results are presented in Table 6 . Accurate recoveries were achieved in all solutions.

\subsection{Determination of gold(III) in certified reference materials}

A $0.5 \mathrm{~g}$ sample was accurately weighed and placed in a $50 \mathrm{ml}$ Erlenmeyer flask. To this, $10 \mathrm{ml}$ of concentrated nitric acid and $5 \mathrm{ml}$ of concentrated 
Table 7 Determination of gold(III) in certified reference materials.

\begin{tabular}{|c|c|c|c|c|}
\hline \multirow{2}{*}{ Sample No. } & \multirow{2}{*}{$\begin{array}{c}\text { Certified reference material } \\
\text { (composition) }\end{array}$} & \multicolumn{2}{|c|}{ Gold(III) $(\mu \mathrm{g} / \mathrm{ml})$} & \multirow{2}{*}{ Error $(\%)$} \\
\hline & & Certified value & Found $^{\mathrm{a}}$ & \\
\hline 1 & $\begin{array}{c}\text { OXG 60 } \\
\left(\mathrm{SiO}_{2}, \mathrm{Al}_{2} \mathrm{O}_{3}, \mathrm{Na}_{2} \mathrm{O}, \mathrm{K}_{2} \mathrm{O}, \mathrm{CaO}, \mathrm{MgO},\right. \\
\left.\mathrm{TiO}_{2}, \mathrm{MnO}, \mathrm{P}_{2} \mathrm{O}_{5}, \mathrm{Fe}_{2} \mathrm{O}_{3}{ }^{\mathrm{b}}, \mathrm{LOI}\right)\end{array}$ & 1.025 & 1.019 & 0.59 \\
\hline 2 & $\begin{array}{c}\text { OXG } 56 \\
\left(\mathrm{SiO}_{2}, \mathrm{Al}_{2} \mathrm{O}_{3}, \mathrm{Na}_{2} \mathrm{O}, \mathrm{K}_{2} \mathrm{O}, \mathrm{CaO}, \mathrm{MgO}\right. \\
\left.\mathrm{TiO}_{2}, \mathrm{MnO}, \mathrm{P}_{2} \mathrm{O}_{5}, \mathrm{Fe}_{2} \mathrm{O}_{3}{ }^{\mathrm{b}}, \mathrm{LOI}\right)\end{array}$ & 0.611 & 0.607 & 0.65 \\
\hline 3 & $\begin{array}{c}\mathrm{SH} 24 \\
\left(\mathrm{SiO}_{2}, \mathrm{Al}_{2} \mathrm{O}_{3}, \mathrm{Na}_{2} \mathrm{O}, \mathrm{K}_{2} \mathrm{O}, \mathrm{CaO}, \mathrm{MgO},\right. \\
\left.\mathrm{TiO}_{2}, \mathrm{MnO}, \mathrm{P}_{2} \mathrm{O}_{5}, \mathrm{Fe}^{\mathrm{b}}, \mathrm{S}\right)\end{array}$ & 1.326 & 1.318 & 0.60 \\
\hline
\end{tabular}

a average of best three determinations among five determinations

$\mathrm{b}$ iron is masked by using fluoride

Table 8 Determination of gold(III) in water samples.

\begin{tabular}{c|c|c|c|c}
\hline \multirow{2}{*}{ Sample No. } & \multirow{2}{*}{ Sample } & \multicolumn{2}{|c|}{ Gold(III) $(\mu \mathrm{g} / \mathrm{l})$} & \multirow{2}{*}{ Recovery $(\%)$} \\
\cline { 3 - 4 } & & Added & Found $^{\mathrm{a}}$ & \multirow{2}{*}{100} \\
\hline \multirow{2}{*}{1} & Jewels waste water $^{\mathrm{b}}$ & 0 & 124 & 224 \\
& & 100 & 28.0 & 101 \\
\hline
\end{tabular}

${ }^{a}$ average of best three determinations among five determinations

${ }^{\mathrm{b}}$ Jewellers shops from Anantapur

${ }^{\mathrm{c}}$ Jewellers shops area, Anantapur

hydrochloric acid were added carefully, covering the flask with a watch glass until the brisk reaction subsided. The solution was heated and simmered gently after the addition of $5 \mathrm{ml}$ of concentrated nitric acid, until all carbides were decomposed. The solution was evaporated carefully to dense white fumes to drive off the oxides of nitrogen and then cooled to room temperature. After suitable dilution with distilled water, the contents of the flask were warmed to dissolve the soluble salts. The solution was then cooled and neutralized with a dilute ammonium hydroxide solution. The resulting solution was filtered, if necessary, through a Whatman No. 42 filter paper into a $50 \mathrm{ml}$ calibrated flask. The residue was washed with a small volume of hot water and the volume was made up to the mark with distilled water.

A suitable aliquot of the above solution was taken in a $10 \mathrm{ml}$ flask and used for the determination of gold(III) by the general procedure. The results are presented in Table 7.

\subsection{Determination of gold(III) in water samples}

Each water sample $(250 \mathrm{ml})$ filtered with Whatman No. 40 was mixed with $10 \mathrm{ml}$ of concentrated nitric acid in a $500 \mathrm{ml}$ distillation flask. The sample was digested in the presence of an excess of $\mathrm{KMnO}_{4}$ solution according to the method recommended by Fifield et al. [10]. The solution was cooled and neutralized with a dilute ammonium hydroxide solution. The digest was transferred into a $50 \mathrm{ml}$ calibrated flask and diluted up to the mark with distilled water. Aliquots of these solutions were taken for analysis for the determination of gold(III) and the results are presented in Table 8.

\subsection{Determination of gold(III) in pharmaceutical samples}

About $3 \mathrm{~g}$ of sample (Vasanta kusumakar ras, swarna guggul) was heated after treating it with $10 \mathrm{ml}$ of $1 \mathrm{~N}$

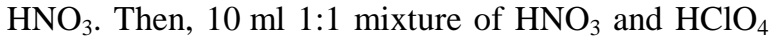
were added and the solution was heated until dryness. The residue was dissolved in hot doubly distilled water and $5 \mathrm{ml}$ of $1 \mathrm{M} \mathrm{HCl}$ were added. The solution was filtered and diluted to $50 \mathrm{ml}$ with doubly distilled water.

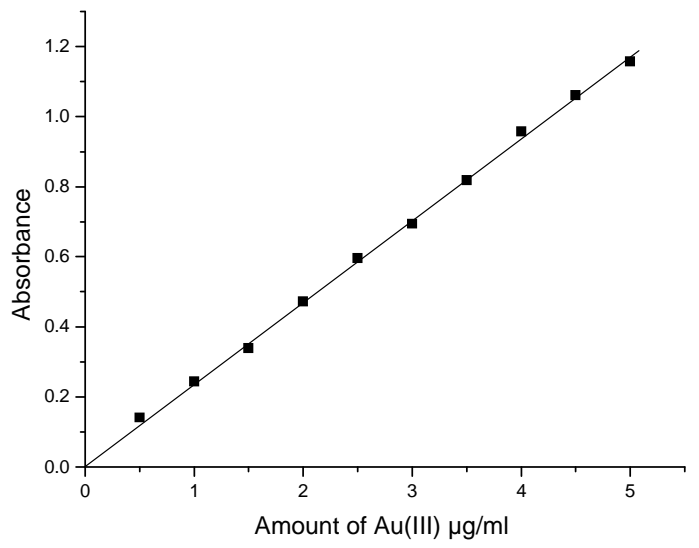

Fig. 4 Zero order Beer's law plot of [Au(III)DMHBIH] complex. 
Table 9 Determination of gold(III) in pharmaceutical samples.

\begin{tabular}{|c|c|c|c|c|}
\hline \multirow{2}{*}{\multicolumn{2}{|c|}{ Sample }} & \multicolumn{2}{|l|}{ Gold(III) $(\mu \mathrm{g} / \mathrm{mg})$} & \multirow{2}{*}{ Error $(\%)$} \\
\hline & & Present & Found $^{\mathrm{a}}$ & \\
\hline \multicolumn{2}{|l|}{ Swarna Guggulu $^{\text {b }}$} & 0.016 & 0.0158 & -0.02 \\
\hline \multicolumn{2}{|c|}{ Vasanta Kusumakar Ras $^{c}$} & 0.07 & 0.071 & +1.43 \\
\hline \multicolumn{5}{|c|}{${ }^{a}$ average of best three determinations among five determinations } \\
\hline \multicolumn{5}{|c|}{${ }^{\mathrm{b}}$ Swarna guggulu: each $125 \mathrm{mg}$ tablet contains } \\
\hline Swarna bhasma & $-2.0 \mathrm{mg}$ & Kumkuma & $-3.0 \mathrm{mg}$ & \\
\hline Ashwagandha & $-20.0 \mathrm{mg}$ & Maha yogaraj guggulu & $-100.0 \mathrm{mg}$ & \\
\hline \multicolumn{5}{|c|}{${ }^{\mathrm{c}}$ Vasanta Kusumakar Ras: each 125 mg tablet contains } \\
\hline Swarna bhasma & $-8.62 \mathrm{mg}$ & Rajat bhasma & $-8.62 \mathrm{mg}$ & \\
\hline Vanga bhasma & $-12.93 \mathrm{mg}$ & Naga bhasma & $-12.93 \mathrm{mg}$ & \\
\hline Lauha bhasma & $-17.24 \mathrm{mg}$ & Abhraka bhasma & $-17.24 \mathrm{mg}$ & \\
\hline Prarala bhasma & $-17.24 \mathrm{mg}$ & Mukta bhasma & $-17.24 \mathrm{mg}$ & \\
\hline Rasa sindhur & $-17.24 \mathrm{mg}$ & & & \\
\hline
\end{tabular}

Table 10 Determination of gold(III).

\begin{tabular}{c|l|c|c|c}
\hline Sample No. & \multicolumn{1}{|c|}{ Reagent } & \multicolumn{1}{|c}{$\lambda_{\max }(\mathrm{nm})$} & $\begin{array}{c}\text { Molar } \\
\text { absorptivity }\end{array}$ & Reference \\
\hline 1 & $\begin{array}{l}3,5 \text {-dimethoxy-4-hydroxy-2-amino acetophenone } \\
\text { isonicotinoyl hydrazone }\end{array}$ & 490 & $3.45 \times 10^{4}$ & {$[20]$} \\
\hline 2 & Mepazine hydrochloride & 514 & $2.18 \times 10^{4}$ & {$[21]$} \\
\hline 3 & $\begin{array}{l}3,3-\text {-dimethyl-2-[4-(N-methyl-N-chloroethyl)amido } \\
\text { phenylethylene]indole }\end{array}$ & 555 & $7.29 \times 10^{4}$ & {$[22]$} \\
\hline 4 & Chrompyrazol & 580 & $7.50 \times 10^{4}$ & {$[23]$} \\
\hline 5 & Ethyl violet & 551 & $5.04 \times 10^{4}$ & {$[24]$} \\
\hline 6 & Rhodamine B & 555 & $9.70 \times 10^{4}$ & {$[25]$} \\
\hline 7 & 5-(2-pyridyl)methylene rhodamine & 418 & $1.10 \times 10^{4}$ & {$[26]$} \\
\hline 9 & Morin & 420 & $2.02 \times 10^{4}$ & {$[27]$} \\
\hline 10 & 5(2,4Dihydroxybenzylidine) rhodamine(DHBR) & 558 & $8.45 \times 10^{4}$ & {$[28]$} \\
\hline 11 & $\begin{array}{l}\text { 2'-Aminoacetophenone isonicotinoyl hydrazone(2'- } \\
\text { AAINH) }\end{array}$ & 440 & $3.50 \times 10^{4}$ & {$[29]$} \\
\hline 12 & Propericiazine & 511 & $3.85 \times 10^{4}$ & {$[30]$} \\
\hline 13 & Ethopazine hydrochloride(EPI) & 513 & $2.00 \times 10^{4}$ & {$[31]$} \\
\hline
\end{tabular}

The gold(III) in this solution was determined by the recommended derivative procedure from a predetermined calibration plot. Results are presented in Table 9.

\section{Conclusions}

The present method using 3,5-dimethoxy4-hydroxybenzaldehyde isonicotinoyl hydrazone (DMHBIH) as spectrophotometric reagent for the determination of gold(III) in aqueous medium in presence of Triton X-100 surfactant is sensitive and simple. Many of the methods involve either heating at a specific temperature $[16,17]$ or extraction $[18,19]$ of the reaction mixture. However, heating at a specific temperature for a long time is laborious and time consuming. The determination of gold(III) using DMHBIH is not laborious and there is no need of heating or extraction of the components. Further, the reagent is easy to synthesize using available chemicals. Spectrophotometric determination of gold(III) with this method is compared with other reagents and presented in Table 10 [20-31]. The present method is simple, rapid, selective and more precise for the determination of gold(III).

\section{Acknowledgements}

The authors thank Jawaharlal Nehru Technological University, Anantapur for providing research facilities 


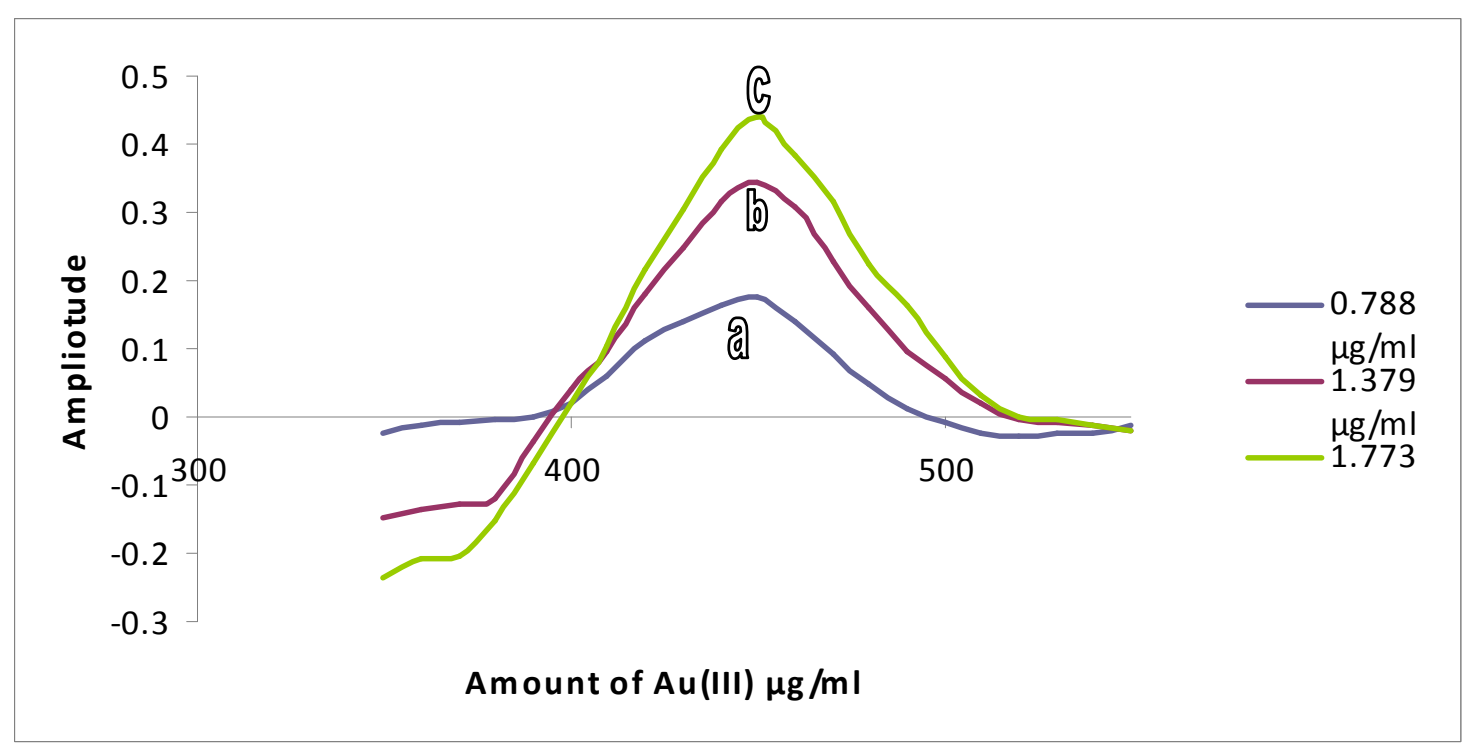

Fig. 5 First order Beer's law derivative spectra of $\mathrm{Au}(\mathrm{III})-\mathrm{DMHBIH}$ complex: (a) $0.788 \mu \mathrm{g} / \mathrm{ml}$ of $\mathrm{Au}(\mathrm{III})$; (b) $1.379 \mu \mathrm{g} / \mathrm{ml}$ of $\mathrm{Au}(\mathrm{III})$; (c) $1.773 \mu \mathrm{g} / \mathrm{ml}$ of $\mathrm{Au}(\mathrm{III})$.

and one of the authors thanks the University Grants Commission for providing a Teacher fellowship under the UGC-FDP programme to carry out the research work.

\section{References}

[1] R.B. Singh, P. Jain, R.P. Singh, Talanta 29 (1982) 77.

[2] K.B. Chandrasekhar, K. Hussain Reddy, Indian J. Chem. 41 (2002) 1643.

[3] K. Hussain Reddy, K.B. Chandrasekhar, Indian J. Chem. 40 (2001) 727.

[4] M. Ramesh, K.B. Chandrasekhar, K. Hussain Reddy, Indian J. Chem. 39 (2000) 1337.

[5] M. Rameswara rao, K. Hari, N. Devanna, K.B. Chandrasekhar, Asian J. Chem. 2 (2008) 1402.

[6] G. Narender Reddy, K.B. Chandrasekhar, N. Devanna, K.N. Jayaveera, Asian J. Chem. 3 (2008) 2257.

[7] V. Kiran Kumar, M. Rameswara rao, K.B. Chandrasekhar, N. Devanna, Asian J. Chem. 3 (2008) 2197.

[8] G.V.S. Vallinath, K. Aruna bai, N. Devanna, K.B. Chandrasekhar, Proc. 4th Int. Congr. Chemistry and Environment, ICCE-2009, Thailand, 2009, Vol. 4, p. 115.

[9] G.V.S. Vallinath, K. Aruna bai, N. Devanna, K.B. Chandrasekhar, Proc. 11th Int. Conf. Int. Acad. Sci., CONIAPSXI, Allahabad, 2010, Vol. 11, p. 177.

[10] G.V.S. Vallinath, K.B. Chandrasekhar, N. Devanna, Proc. Natl. Sem. Recent Developments in Inorganic, Organic Materials and Electro-
Organic Synthesis, RDIOMES, SKU, Anantapur, 2010, p. 82.

[11] K. Aruna Bai, G.V.S. Vallinath, N. Devanna, K.B. Chandrasekhar, Proc. Natl. Sem. Recent Developments in Inorganic, Organic Materials and Electro-Organic Synthesis, RDIOMES, SKU, Anantapur, 2010, p. 77.

[12] K. Hayashi, Y. Sasaki, M. Nakanishi, S. Ito, Bunseki Kagaku 19 (1970) 1673.

[13] K. Hayashi, Y. Sasaki, S. Ito, Bunseki Kagaku 21 (1972) 1338.

[14] K. Hayashi, Y. Sasaki, S. Taga Shira, K. Hiratc, Anal Chem. Acta. 198 (1987) 271.

[15] S. Taga Shira, K. Onoue, Y. Murakami, Y. Sasaki, Anal Sci. 8 (1992) 307.

[16] B.R. Naik K.K. Desai, Asian J. Chem. 18(4) (2006) 3176.

[17] Y. Sasaki, S. Tagashira, Y. Murakami, M. Ichikawa, Anal Sci. 14 (1998) 1603.

[18] R. Dass, A. Kumar, Indian J. Chem. 43A (2004) 576.

[19] A.K. Mallik, K.N. Kaul, B.S. Lark, W. Faubel, A.L.J. Rao, Turk J. Chem. 25 (2001) 99.

[20] S. Haribabu, K. Suvardhan, K. Suresh Kumar, K.M. Reddy, D. Rekha, P.Chiranjeevi, J. Hazardous Mater. 120(1-3) (2005) 213.

[21] H. Sanke Gowde, K.N. Thimmaiah, Indian J. Chem. 14 (1976) 632.

[22] X. Zhang, D.B. Luo, H. Fang, Yankuang Ceshi 7 (1988) 184.

[23] P.N. Nesterenko, V.M. Ivanon, Zh. Anal. Khim 37 (1982) 1977.

[24] H.K. Lin, R.Q. Yu, Huaxue Tongbao 4 (1965) 244.

[25] B.J. Macnulty, L.D. Woollard, Anal. Chim. Acta 13 (1955) 154. 
[26] C.G. Alfonso, J.L. Gomez Ariza, Microchem J. 26 (1981) 574-85.

[27] M. Balcerzak, A. Kosiorek, E. Swiecicka, J. Anal Chem 61 (2006) 119-23.

[28] F.M. El-Zawawy, M.F. El-Shahat, A.A. Mohamed, Analyst 120 (1995) 549-54.
[29] M. Gangadharappa, P.R. Reddy, V.R. Reddy, S. Reddy, J. Indian Chem. Soc. 81 (2004) 525-7.

[30] H.S. Gowda, A.T. Gowda, N.M. Made Gowda, Microchem J. 30 (1984) 259-65.

[31] M.B. Melwanki, S.P. Masti, J. Seetharamappa, Turk. J. Chem. 26 (2002) 17-22. 